\title{
SOURGRASS CONTROL IN RESPONSE TO THE ASSOCIATION OF 2,4-D TO ACCASE INHIBITOR HERBICIDES
}

\author{
CONTROLE DE CAPIM-AMARGOSO EM RESPOSTA À ASSOCIAÇÃO DE 2,4-D A \\ HERBICIDAS INIBIDORES DA ACCASE
}

\author{
Hugo Leonardo Lima GOMES ${ }^{\text {; }}$ Vinícius Cesar SAMBATTI² ${ }^{2}$ Giliardi DALAZEN ${ }^{3 *}$ \\ 1. Department of Agronomy, State University of Londrina, Londrina, PR, Brazil; 2. Post Graduate Program in Conservation Agriculture, \\ IAPAR, Londrina, PR, Brazil; 3. Department of Agronomy, State University of Londrina, Londrina, PR, Brazil. \\ *giliardidalazen@gmail.com
}

\begin{abstract}
ACCase inhibitor herbicides are widely used to control poaceae such as sourgrass (Digitaria insularis). However, these herbicides are selective for eudicots, which requires the use of broadleaf herbicides in areas with broadleaf and narrow leaf weeds. The objective of this study was to evaluate the effect of the association ACCase inhibitors and 2,4-D for the control of sourgrass. Two experiments were carried out under greenhouse conditions. The first experiment evaluated the effect of associating 2,4-D and graminicides to control of sourgrass, using dose-response curves for the herbicides clethodim, quizalofop- $P$-tefuril and clethodim + quizalofop- $P$-tefuril. In the second experiment, due to the results of the first one, the necessary period between the application of 2,4-D and the graminicides was evaluated in order to avoid antagonism in sourgrass. The results show that the herbicide clethodim, at the recommended dose, has its efficiency reduced in about $8 \%$ when applied in association with $2,4-\mathrm{D}$. As for the herbicide quizalofop- $P$-tefuril, this effect was higher, causing a reduction of $39 \%$ in control. However, the association of 2,4-D to the mixture of clethodim + quizalofop- $P$-tefuril did not result in antagonism. It takes nine and 12 days between the application of 2,4-D and the graminicides clethodim and quizalofop- $P$-tefuril, respectively, for there to be no antagonism.
\end{abstract}

KEYWORDS: Herbicide tank mix. Antagonism. Clethodim. Quizalofop-P-tefuril. Digitaria insularis.

\section{INTRODUCTION}

Sourgrass (Digitaria insularis) is one of the main grass weeds to infest soybean crops in South America, mainly in the mid-west and mid-south regions of Brazil (LÓPEZ-OVEJERO et al., 2017). The chemical method has been the most used to control this plant in agricultural environments, mainly by spraying the herbicide glyphosate. However, the indiscriminate use of this herbicide led to the selection of resistant plant biotypes in most areas of production (BARROSO et al., 2014). The first glyphosate-resistant sourgrass recorded in Brazil was in 2008, in Guaíra, western region of the state of Paraná (HEAP, 2019). Since then, resistance has been dispersed by practically all areas of production (CARVALHO et al., 2011; LÓPEZOVEJERO et al., 2017), making the practices for chemical control of this species difficult and costly.

Acetyl-CoA carboxylase enzyme (ACCase) inhibitor herbicides are the main alternative to control glyphosate-resistant sourgrass. These herbicides act on the meristems, inhibiting the synthesis of lipids (BURKE et al., 2006), and consequently the production of new membranes and the growth and development of growing tissues (NALEWAJA; MATYSIAK; SZELEZNIAK,
1994). However, ACCase-inhibitor herbicides are classified as graminicides and do not act on broadleaved species (eudicots). In practice, the occurrence of sourgrass, in most cases, is not isolated. Typically, weed infestation includes a great diversity of weeds, including non-poaceae plants. Thus, it is necessary to associate other herbicides to ACCase inhibitors.

Like sourgrass, horseweed (Conyza spp.) is a plant that can be found in the mid-west and southwest regions of Brazil (LAZAROTO; FLECK; VIDAL, 2008), and also presents glyphosateresistant biotypes (LAMEGO; VIDAL, 2008). In addition to horseweed, other species of eudicots are glyphosate-tolerant, including morning glory (Ipomoea spp.), benghal dayflower (Commelina benghalensis) and tropical Mexican clover (Richardia brasiliensis). Among the herbicides used to control these weeds, 2,4-dichlorophenoxyacetic acid $(2,4-D)$ has shown to be efficient (VARGAS et al., 2007). The association of graminicides and broadleaf herbicides can bring some operational benefits, such as rationing time, optimizing the use of machinery and reducing labor. At the same time, there are reports in the literature of antagonistic effects 2,4-D over the action of ACCase-inhibitor graminicides for the control of poacea, such as 
ryegrass (TREZZI et al., 2007). However, for sourgrass, these studies have not yet been performed.

The initial objective of this study was to determine the effect of the association of 2,4-D to ACCase-inhibitor herbicides (clethodim, quizalofop- $P$-tefuril, and clethodim + quizalofop- $P$ tefuril) for the control of sourgrass (Digitaria insularis). However, the antagonism between the herbicides obtained in the first experiment led to a second experiment, which aimed to determine the necessary interval between the application of 2,4-D and graminicides for the antagonism not to occur.

\section{MATERIAL AND METHODS}

\section{Plant material and experimental conditions common to both experiments}

The sourgrass seeds were sown in plastic trays $(30 \times 20 \times 7 \mathrm{~cm})$ containing organic substrate. The trays were kept in a greenhouse and irrigated periodically. After germination, the seedlings were transplanted individually into $1000 \mathrm{~cm}^{3}$ pots, containing a mixture of soil and sand $(3: 1)$, to which NPK 5-20-20 fertilizer was added at $2.5 \mathrm{~g} \mathrm{~kg}^{-1}$ of substrate. The plants were kept in a greenhouse and irrigated daily, until the treatments were applied.

The treatments were applied with a backpack sprayer pressurized with carbon dioxide $\left(\mathrm{CO}_{2}\right)$, equipped with a bar with two fan-type tips with air induction, with a working pressure of $30 \mathrm{psi}$ and spray volume of $150 \mathrm{~L} \mathrm{ha}^{-1}$. The treatments were applied when the sourgrass plants had two to three tillers. In all treatments containing graminicides, the adjuvant Lanzar (phosphoric acid ethoxylated alkyl ester, $280 \mathrm{~g} \mathrm{~L} \mathrm{~L}^{-1}$, Arysta LifeScience, Brazil) was added in the proportion of $0.5 \%(\mathrm{v} / \mathrm{v})$.

To determine the shoot dry mass (SDM), the plants were harvested and oven dried at $65^{\circ} \mathrm{C}$ for 72 hours. The control data were expressed as percentage of control relative to the non-treated check treatment, and SDM data were expressed in $g$ plant $^{-1}$.

\section{Association of 2,4-D to the herbicides clethodim and quizalofop- $P$-tefuril in the control of sourgrass}

The experiment was conducted in a completely randomized design with four replications. Treatments were organized in a factorial scheme $(2 \times 3 \times 7)+2$, in which factor $\mathrm{A}$ was formed by the absence or presence of the herbicide 2,4-D (DMA $806 \mathrm{BR}, 806 \mathrm{~g} \mathrm{~L}^{-1}$, Dow Agrosciences, Brazil) in a dose of $1,209 \mathrm{~g} \mathrm{ha}^{-1}$; factor B was represented by the ACCase enzyme inhibitors herbicides clethodim (Select 240 EC, 240 $\mathrm{g} \mathrm{\textrm {L } ^ { - 1 }}$, Arysta LifeScience, Brazil), quizalofop (quizalofop- $P$-tefuril, Panther $120 \mathrm{EC}, 120 \mathrm{~g} \mathrm{~L}^{-1}$, Arysta LifeScience, Brazil) and the admixture clethodim + quizalofop (Select $240 \mathrm{EC}+$ Panther $120 \mathrm{EC}$ ); and factor $\mathrm{C}$ was formed by doses of the herbicides (zero, $\mathrm{x} / 8, \mathrm{x} / 4, \mathrm{x} / 2, \mathrm{x}, 2 \mathrm{x}$ e $4 \mathrm{x}$, where $\mathrm{x}$ is the dose recommended by the manufacturer). For clethodim, the recommended dose was $96 \mathrm{~g} \mathrm{ha}^{-1}$, and for quizalofop, $72 \mathrm{~g} \mathrm{ha}^{-1}$. To reach the recommended dose (dose $\mathrm{x}$ ) of the admixture clethodim + quizalofop, half the recommended dose for each graminicide was used. Two check treatments were also evaluated, one containing only water (non-treated) and the other with the recommended dose of 2,4-D $\left(1,209 \mathrm{~g} \mathrm{ha}^{-1}\right)$.

The variables assessed were visual percentage for control of sourgrass plants at 7, 14, 21 and 28 days after application of treatments (DAT) and shoot dry mass (SDM) at 28 DAT. The data were submitted to variance analysis and adjusted by non-linear regression corresponding to the equation $\mathrm{y}=\mathrm{a} /\left[1+\left(\mathrm{x} / \mathrm{x}_{0}\right)^{\mathrm{b}}\right]$, where: $\mathrm{y}=$ dependent variable (control or SDM); $a=$ maximum asymptote; $\mathrm{x}=$ independent variable (herbicidal dose in $\mathrm{g} \mathrm{ha}^{-1}$ ); $\mathrm{b}=$ slope of the curve; $\mathrm{x}_{0}=$ herbicidal dose $\left(\mathrm{g} \mathrm{ha}^{-1}\right)$ responsible for reducing the dependent variable to the level corresponding to $50 \%$ of the maximum asymptote value (a). The significance of the effect of adding 2,4-D was analyzed using the t-test $(p<0.05)$ for each dose of graminicide. The parameter $\mathrm{x}_{0}$ was used to estimate $\mathrm{ED}_{50}$ and $\mathrm{ED}_{80}$ (dose required to cause $50 \%$ and $80 \%$ control of sourgrass), and $\mathrm{GR}_{50}$ (dose needed to reduce in $50 \%$ the accumulation of SDM).

\section{Interval between the application of 2,4-D and graminicides in the control of sourgrass}

The experiment was conducted in a completely randomized design with four replications. The experiment was organized in a factorial scheme $(2 \times 7)$, in which factor $\mathrm{A}$ was formed by the herbicides clethodim and quizalofop, at doses of $96 \mathrm{~g} \mathrm{ha}^{-1}$ and $72 \mathrm{~g} \mathrm{ha}^{-1}$, respectively. Factor B was composed of different intervals of application of the herbicide 2,4-D (1.209 $\left.\mathrm{g} \mathrm{ha}^{-1}\right)$ and the graminicides, with zero (application on the same day), 3, 6, 9, 12 and 15 days, in addition to the exclusive application of each graminicide. 2,4-D was previously applied to graminicides, according to the application intervals. The evaluations of control and SDM were carried out at 28 DAT. The data were submitted to analysis of variance and 
adjusted by the second order polynomial regression $\mathrm{y}=\mathrm{y}_{0}+\mathrm{ax}+\mathrm{bx}^{2}$.

\section{RESULTS}

\section{Association of 2,4-D to the herbicides clethodim and quizalofop- $P$-tefuril in the control of sourgrass}

At 7 DAT, the association of 2,4-D with clethodim resulted in an increase in the control of the sourgrass plants at the doses of graminicide from $24 \mathrm{~g} \mathrm{ha}^{-1}$ (Figure 1A). In this evaluation, the control observed with the isolated use of clethodim was always below $10 \%$, whereas when together with $2,4-\mathrm{D}$ the control reached $20 \%$. This result is due to the presence of necrotic spots in some leaves of sourgrass that received application of 2,4-D in association with clethodim (Figure 2).

In the following evaluations, the effect of the association of 2,4-D to clethodim was dependent on the dose of graminicide. At doses lower than recommended $\left(96 \mathrm{~g} \mathrm{ha}^{-1}\right)$ the occurrence of
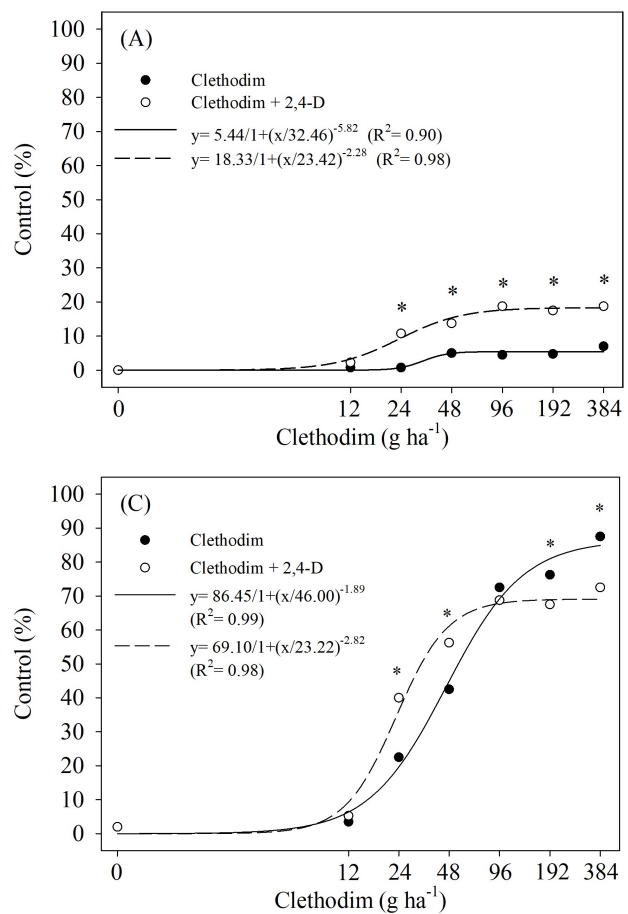

synergism was observed, whereas at doses from the recommended one, additivity or antagonism was observed, depending on the date of the evaluation (Figure 1). At 14 DAT (Figure 1B), at clethodim doses of 96 and $192 \mathrm{~g} \mathrm{ha}^{-1}$, the controls observed were $66 \%$ and $62.5 \%$, respectively. However, with the addition of 2,4-D, control was reduced to $6 \%$ and $15 \%$ at these same doses. At 21 DAT (Figure $1 C)$, the association of 2,4-D in doses from the recommended one resulted in reduction in the control of $4 \%$ to $15 \%$. At 28 DAT (Figures 1D and 3 ), at clethodim doses of 96 and $192 \mathrm{~g} \mathrm{ha}^{-1}$, controls were approximately $85 \%$ when the graminicide was applied alone. However, at the same doses, the addition of 2,4-D reduced control by approximately $8 \%$. At the highest dose of clethodim evaluated, the antagonism was even higher, with reduction in control of $16.25 \%$ with addition of the broadleaf herbicide. This demonstrates that increased dose of clethodim does not reverse the antagonistic effect caused by 2,4-D.
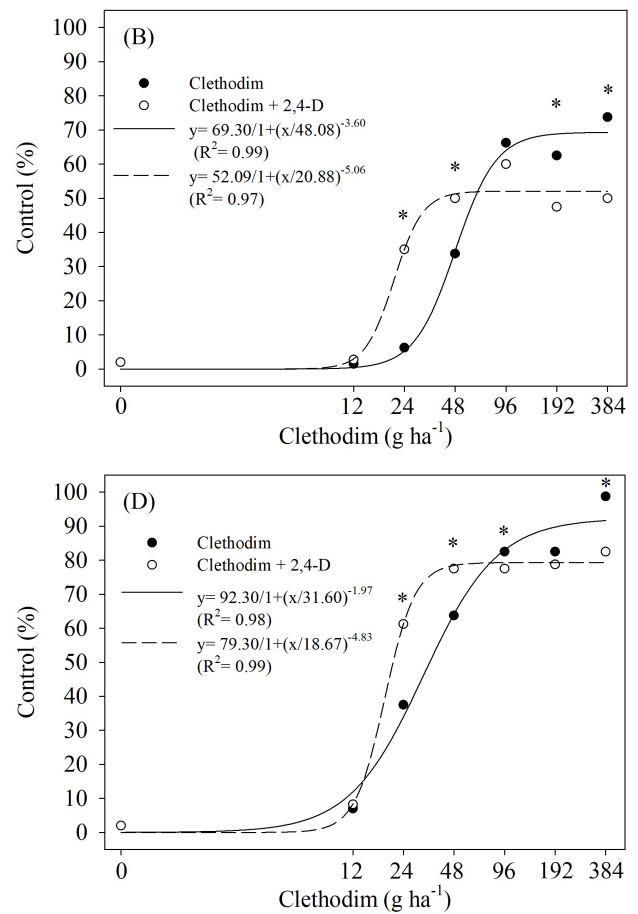

Figure 1. Control (\%) of the sourgrass (Digitaria insularis) plants in response to the application of isolated clethodim or in admixture with 2,4-D (1 $\left.209 \mathrm{~g} \mathrm{ha}^{-1}\right)$ at 7 (A), 14 (B), 21 (C) and 28 (D) days after treatment.

* Statistically different than the $\mathrm{t}$-test $(\mathrm{p}<0.05)$.

The values of $\mathrm{ED}_{50}$ and $\mathrm{ED}_{80}$ estimated by the control regression at 28 DAT confirmed the results observed in the visual evaluation for control (Table 1), in which there was synergism in doses lower than recommended and antagonism in doses higher than recommended. The addition of 2,4-D to clethodim caused a reduction in the value of $\mathrm{ED}_{50}$ and increase in $\mathrm{ED}_{80}$. In the absence of 2,4-D, the value of $\mathrm{ED}_{50}$ was of $34.42 \mathrm{~g} \mathrm{ha}^{-1}$ of clethodim, compared to $20.86 \mathrm{~g} \mathrm{ha}^{-1}$ when the broadleaf herbicide was added. However, for the values of $\mathrm{ED}_{80}$, when clethodim was applied alone, $82.18 \mathrm{~g}$ 
ha $^{-1}$ of clethodim were needed to cause a control of $80 \%$. With the addition of $2,4-\mathrm{D}$, this value was higher than the dose of the graminicide that was used $\left(\mathrm{ED}_{80}>384 \mathrm{~g} \mathrm{ha}^{-1}\right.$ of clethodim). This is explained by the fact that in doses lower than recommended, $50 \%$ of control has already been reached. For control levels considered to be satisfactory, that is, above $80 \%$, at least the recommended doses were necessary, when the occurrence of antagonism was observed.

Table 1. $\mathrm{ED}_{50}$ and $\mathrm{ED}_{80}$ values for the clethodim, quizalofop and clethodim + quizalofop curves for sourgrass control at 28 days after application of treatments (DAT), in response to the association of 2,4-D.

\begin{tabular}{lcccc}
\hline Curves & $\mathrm{ED}_{50} *\left(\mathrm{~g} \mathrm{ha}^{-1}\right)$ & $\begin{array}{c}\text { \% in relation to } \\
\text { the curve } \\
\text { without 2,4-D }\end{array}$ & $\mathrm{ED}_{80} *\left(\mathrm{~g} \mathrm{ha}^{-1}\right)$ & $\begin{array}{c}\text { \% in relation to } \\
\text { the curve } \\
\text { without 2,4-D }\end{array}$ \\
\hline Clethodim & $34.42( \pm 3,91)$ & 100.00 & 82.18 & 100.00 \\
Clethodim + 2,4-D & $20.86( \pm 0,58)$ & 60.59 & $>384$ & $>467.27$ \\
Quizalofop & $10.60( \pm 0,72)$ & 100.00 & 16.31 & 100.00 \\
Quizalofop + 2,4-D & $24.80( \pm 3,83)$ & 233.88 & 130.86 & 802.53 \\
Clethodim + quizalofop & $10.13( \pm 1,04)$ & 100.00 & 23.00 & 100.00 \\
Clethodim + quizalofop + 2,4-D & $10.99( \pm 0,76)$ & 108.44 & 26.71 & 116.11 \\
\hline
\end{tabular}

* Dose needed to cause $50 \%$ and $80 \%$ of injury in sourgrass.

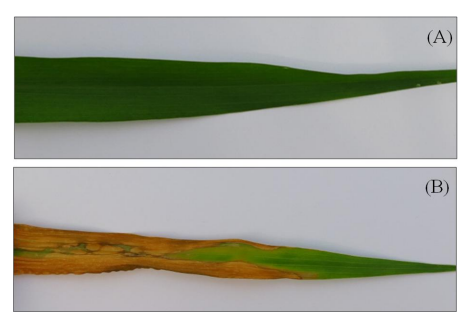

Figure 2. Symptoms in the sourgrass (Digitaria insularis) leaves five days after the application of clethodim isolated (A) or in admixture with 2,4-D (B).

When there is $2,4-\mathrm{D}$, it is possible to observe leaf blade necrosis.

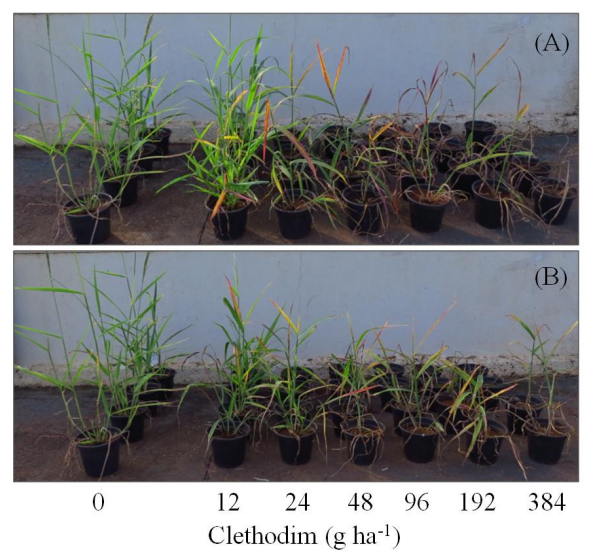

Figure 3. Sourgrass (Digitaria insularis) control at 28 DAT in response to the application of the herbicide clethodim isolated (A) or in admixture with 2,4-D (1,209 $\left.\mathrm{g} \mathrm{ha}^{-1}\right)(\mathrm{B})$.

For the herbicide quizalofop, the results demonstrated an additive effect of the association of 2,4-D at 7 DAT (Figure 4A), regardless of the graminicide dose. At 14 DAT (Figure 4B), additivity was also observed for most doses, except for doses 18 and $288 \mathrm{~g} \mathrm{ha}^{-1}$, in which antagonism was observed, with a reduction of $16 \%$ and $10 \%$ in control, respectively. The evaluation carried out at 21 DAT (Figure 4C) showed a reduction in control with the association of 2,4-D for all doses of quizalofop, except $18 \mathrm{~g} \mathrm{ha}^{-1}$. At the recommended dose $\left(72 \mathrm{~g} \mathrm{ha}^{-1}\right)$, the control was reduced in $16.25 \%$ with association of 2,4-D. In the last evaluation, at 28 DAT (Figure 4D), the antagonism was even higher. When the graminicide was applied at the recommended dose, the control was of $98.75 \%$, while with the association of 2,4-D the control was reduced to $60 \%$, which results in a reduction of approximately $39 \%$. With double the dose of quizalofop, the antagonism was also pronounced, 
with a reduction of more than $20 \%$ in the control with the addition of the auxin to the spray solution. This reduction persisted in the highest tested dose, indicating that an increase in the dose of
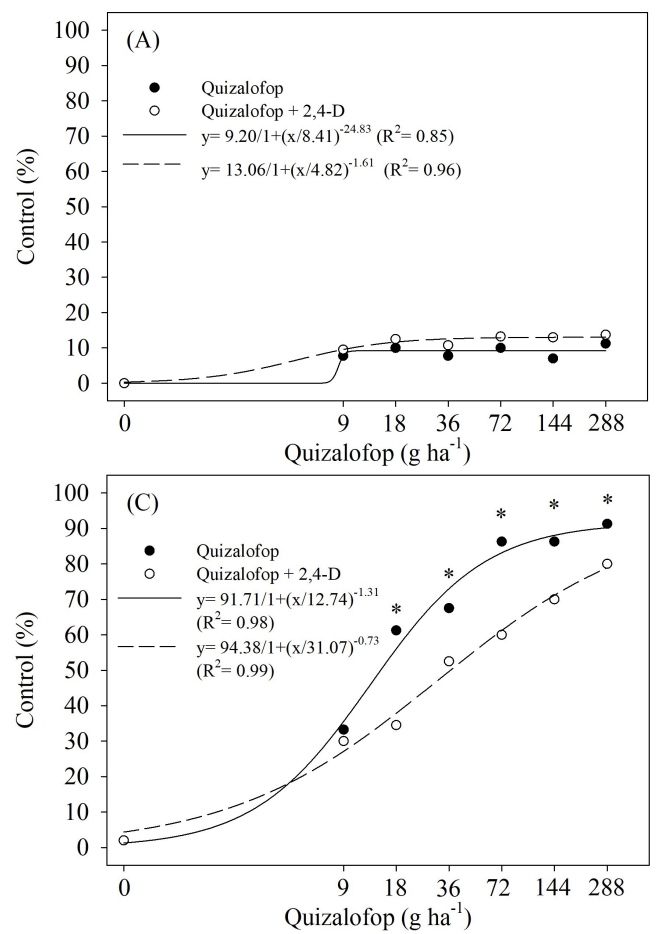

graminicide does not result in antagonism reduction. These differences in control can be seen on Figure 5.
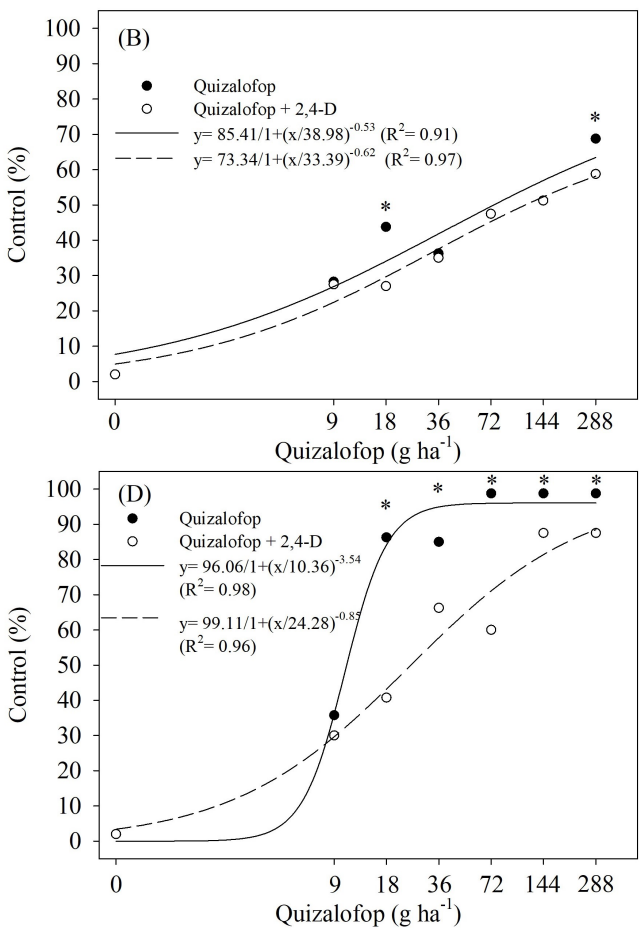

Figure 4. Control (\%) of the sourgrass (Digitaria insularis) in response to the application of isolated quizalofop and in admixture with 2,4-D (1,209 $\left.\mathrm{g} \mathrm{ha}^{-1}\right)$ at 7 (A), 14 (B), 21 (C) and 28 (D) days after treatment.

$*$ indicates statistical significance of the addition of $2,4-\mathrm{D}$ to each dose of the graminicide by the $t$-test $(\mathrm{p}<0.05)$.

The values of $\mathrm{ED}_{50}$ and $\mathrm{ED}_{80}$ confirm the occurrence of antagonism with the association of 2,4-D to quizalofop (Table 1). The $\mathrm{ED}_{50}$ for the isolated application of quizalofop was $10.60 \mathrm{~g} \mathrm{ha}^{-1}$, while with the addition of the broadleaf herbicide this value was $24.80 \mathrm{~g} \mathrm{ha}^{-1}$, representing an addition of $234 \%$ in the dose. Similarly, the value of $\mathrm{ED}_{80}$ went from $16.31 \mathrm{~g} \mathrm{ha}^{-1}$ to $130.86 \mathrm{~g} \mathrm{ha}^{-1}$ with the addition of 2,4-D, representing an increase of over $800 \%$.

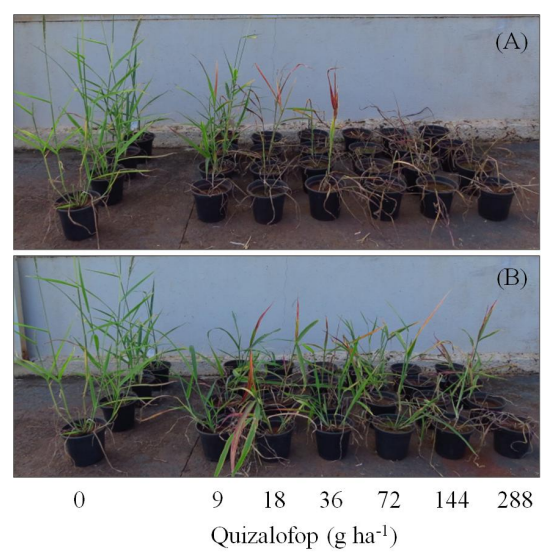

Figure 5. Sourgrass (Digitaria insularis) control at 28 DAT in response to the application of the herbicide quizalofop in isolation (A) or in admixture with 2,4-D $\left(1,209 \mathrm{~g} \mathrm{ha}^{-1}\right)(B)$.

When the two graminicides were applied together, at 7 DAT (Figure 6A) and 14 DAT (Figure $6 \mathrm{~B})$, a slight increase in the control was observed with the addition of $2,4-\mathrm{D}$, of $8 \%$ to $17 \%$, depending of the dose of graminicides. As noted for clethodim (Figure 1), the association of the auxin herbicide 
resulted in necrotic spots on the sourgrass leaves. However, in the evaluations performed at 21 DAT and $28 \mathrm{DAT}$, the occurrence of additivity with the addition of 2,4-D (Figures 6C, 6D and 7) was observed for most doses of graminicides. At the dose that would be considered the recommended dose for the mixture of clethodim and quizalofop $\left(48+36 \mathrm{~g} \mathrm{ha}^{-1}\right)$, adding 2,4-D had no effect, neither synergism nor antagonism. At the same dose,
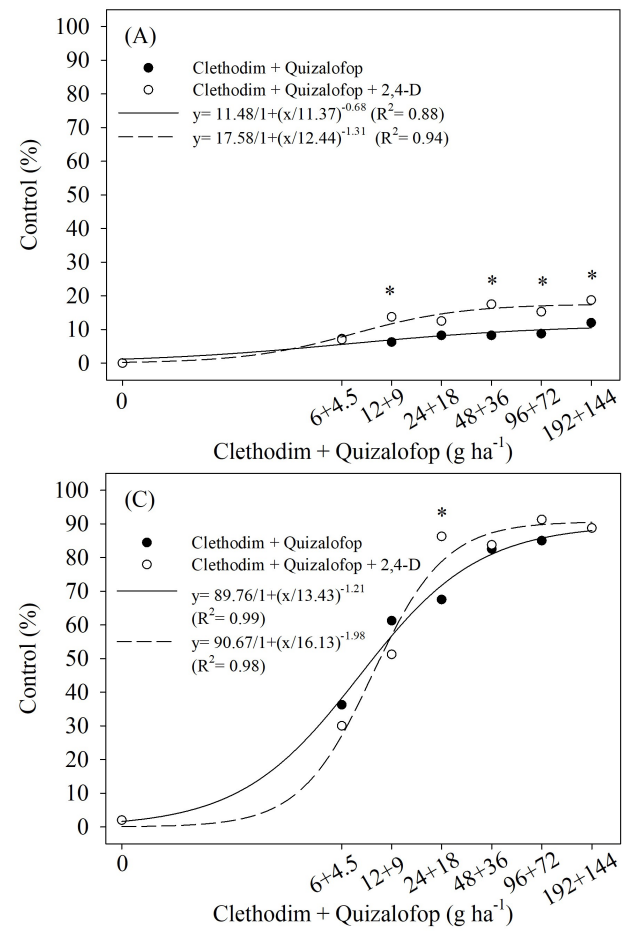

regardless of the association of 2,4-D, the control was $92.5 \%$ at 28 DAT. With a double dose, the control was over $98 \%$, even with the association of 2,4-D. Figure 7 shows the satisfactory control generated by the clethodim mixed with quizalofop, even with the association of 2,4-D. These results corroborate the $\mathrm{ED}_{50}$ and $\mathrm{ED}_{80}$ values (Table 1), in which no significant differences were observed for the addition of 2,4-D.
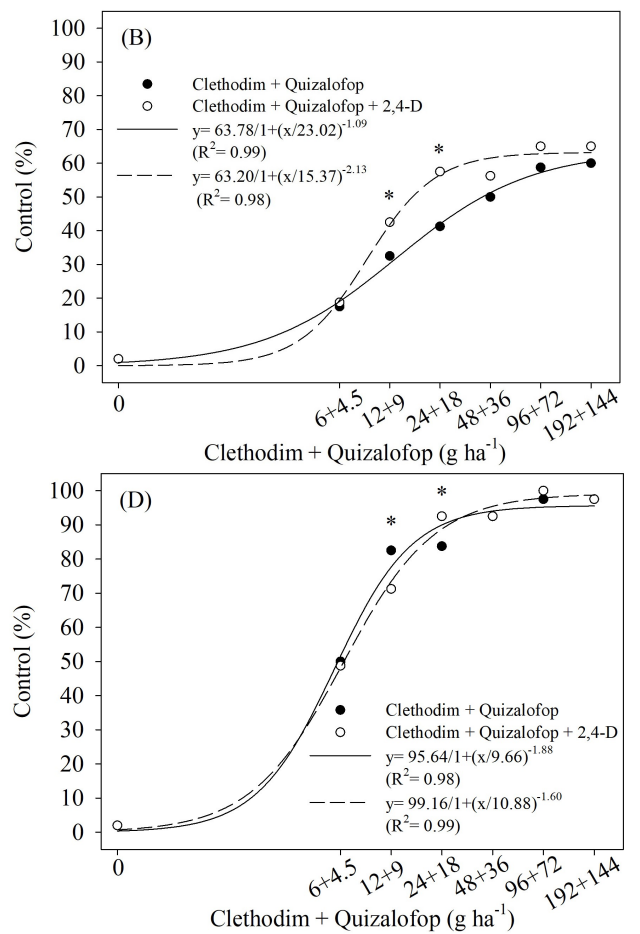

Figure 6. Control (\%) of sourgrass (Digitaria insularis) in response to the application of clethodim + quizalofop isolated or in admixture with 2,4-D (1 $\left.209 \mathrm{~g} \mathrm{ha}^{-1}\right)$ at 7 (A), 14 (B), 21 (C) and 28 (D) days after treatment. * indicates statistical significance of the addition of 2,4-D to each dose of the graminicide by the t-test $(\mathrm{p}<0.05)$.

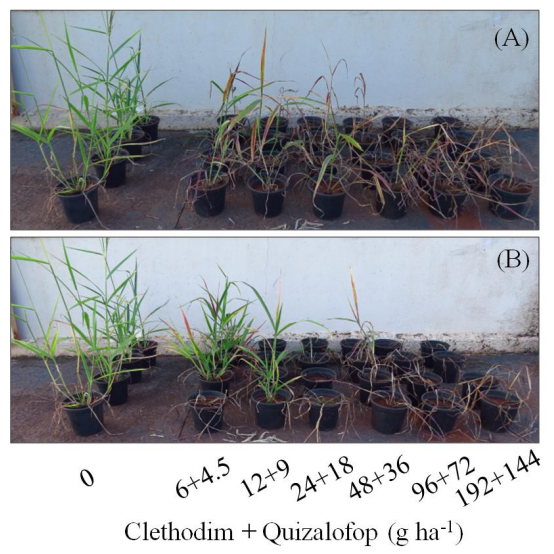

Figure 7. Sourgrass (Digitaria insularis) control at 28 DAT in response to the application of clethodim + quizalofop in isolation (A) or in admixture with 2,4-D $\left(1,209 \mathrm{~g} \mathrm{ha}^{-1}\right)(\mathrm{B})$.

The SDM results (Figure 8) corroborate with the control evaluations for the herbicide clethodim, which at doses below the recommended $\left(96 \mathrm{~g} \mathrm{ha}^{-1}\right)$, and in association with $2,4-\mathrm{D}$, resulted in synergism, with lower aerial growth (Figure 8A). However, in the higher doses tested, the association of the broadleaf herbicide had no effect on this variable. The $\mathrm{GR}_{50}$ value for the curve with $2,4-\mathrm{D}$ 
was approximately 50\% lower than that which did not receive the mixture (Table 2). For the quizalofop (Figure 8B) SDM was higher with the addition of 2,4-D for most doses of the graminicide, confirming a decrease in control due to the occurrence of antagonism. The $\mathrm{GR}_{50}$ was $11.87 \mathrm{~g} \mathrm{ha}^{-1}$ for quizalofop and $16.85 \mathrm{~g} \mathrm{ha}^{-1}$ for quizalofop $+2,4-\mathrm{D}$, representing $41.9 \%$ of increase in this parameter. For the admixture of clethodim + quizalofop, the addition of 2,4-D caused a reduction in the accumulation of SDM for most doses of graminicides (Figure 8C). However, no significant difference was observed in $\mathrm{GR}_{50}$ (Table 2).
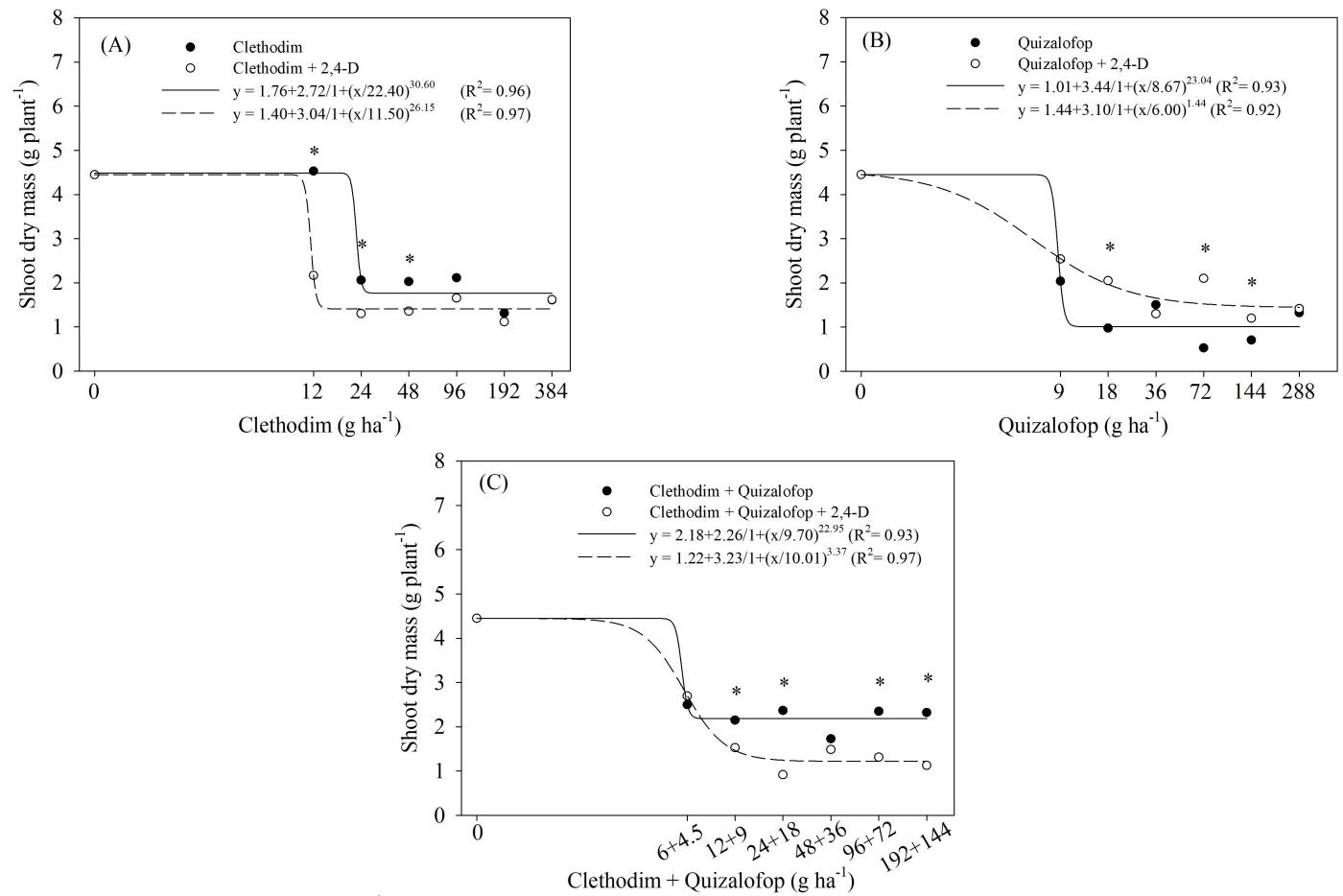

Figure 8. Shoot dry mass ( $\mathrm{g}_{\text {plant }}{ }^{-1}$ ) of sourgrass (Digitaria insularis) plants in response to the application of clethodim (A), quizalofop (B) and clethodim + quizalofop (C), isolated or in admixture with 2,4-D $\left(1,209 \mathrm{~g} \mathrm{ha}^{-1}\right) . *$ indicates statistical significance of the addition of 2,4-D to each dose of the graminicides by the $t$ test $(\mathrm{p}<0.05)$.

Table 2. $\mathrm{GR}_{50}$ values for the clethodim, quizalofop and clethodim + quizalofop curves for the accumulation of aerial dry mass (MSPA) of sourgrass in response to the association with 2,4-D.

\begin{tabular}{lcc}
\hline Curves & $\mathrm{GR}_{50} *\left(\mathrm{~g} \mathrm{ha}^{-1}\right)$ & \% in relation to the curve without 2,4-D \\
\hline Clethodim & $23.60 \pm 5.72$ & 100.00 \\
Clethodim+2,4-D & $11.96 \pm 0.01$ & 50.67 \\
Quizalofop & $11.87 \pm 0.05$ & 100.00 \\
Quizalofop+2,4-D & $16.85 \pm 4.03$ & 141.90 \\
Clethodim +quizalofop & $13.16 \pm 0.02$ & 100.00 \\
Clethodim +quizalofop +2,4-D & $14.46 \pm 1.03$ & 109.90 \\
\hline
\end{tabular}

$*$ Dose needed to reduce $50 \%$ of the shoot dry mass of sourgrass.

Interval between the application of 2,4-D and graminicides for the control of sourgrass

The required period between application of 2,4-D and graminicides varied according to the herbicide. Both the control assessment (Figure 9A) and the SDM accumulation (Figure 9B), performed at 28 DAT, demonstrate that it takes nine days between the application of 2,4-D and clethodim in order for the control to be equivalent to that observed in plants that do not received the broadleaf herbicide. For the herbicide quizalofop, the period is 12 days, although the maximum control was only approximately $80 \%$ at 12 and 15 day intervals. Thus, applications at shorter intervals resulted in a reduction in the control of sourgrass. 

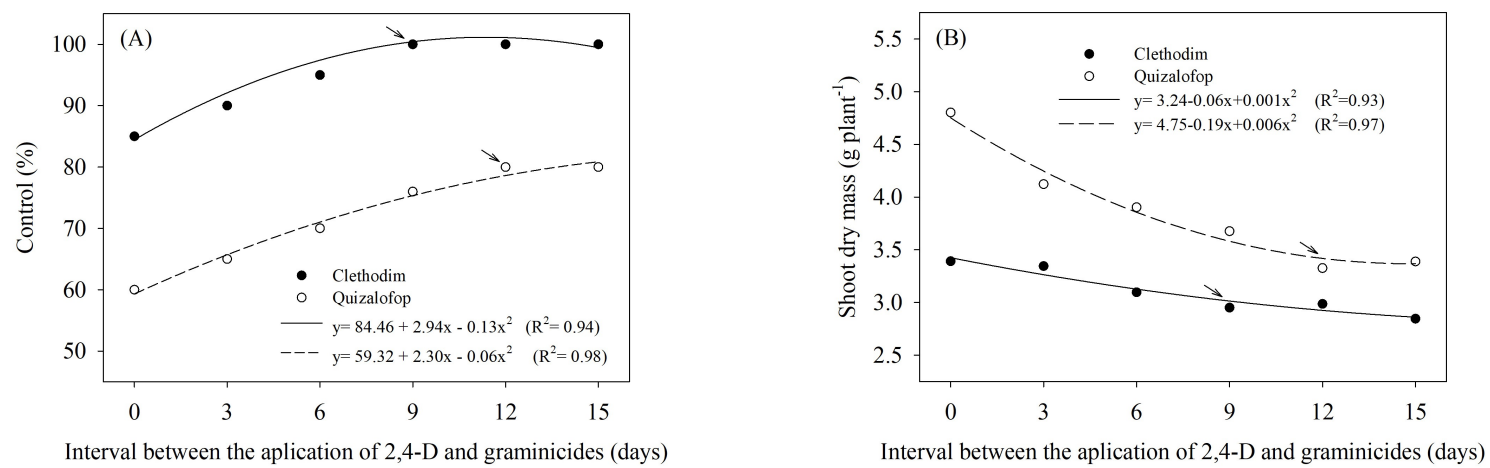

Figure 9. Control (A) and shoot dry mass (B) of sourgrass in response to different intervals between the application of 2,4-D and graminicides.

The arrows indicate the control (A) and shoot dry mass (B) observed in the application of graminicides without previous application of 2,4-D.

\section{DISCUSSION}

Based on the results obtained in the first experiment, the herbicide quizalofop was more efficient than clethodim. At 28 DAT, at the recommended doses, controls were approximately $80 \%$ and $99 \%$ for the herbicides clethodim and quizalofop, respectively (Figures 1D and 2D). The association of clethodim + quizalofop provided control results superior to clethodim and similar to the application of quizalofop (Figure 3D). A similar result was observed by Barroso et al. (2014), who found that the applications of quizalofop or haloxyfop were more efficient in the control of sourgrass when compared to clethodim. In relation to the admixture, the association of quizalofop and clethodim provided control of southern sandbur (Cenchrus echinatus) 33\% higher than clethodim applied in isolation (BARROSO et al., 2010).

Although cyclohexanedione (DIMs) and aryloxyphenoxypropionate (FOPs) herbicides inhibit the same action site, the ACCase enzyme, their chemical structures are different, which results in variation in the affinity with the enzyme active site. The active site of the ACCase enzyme is formed by several amino acids, but only a few of them are shared by both chemical groups (RENDINA et al., 1990; LIU et al., 2007). Both the amino acids asparagine 2078 and cysteine 2088 are binding sites for FOPs and DIMs in the ACCase enzyme. The other amino acids used in the binding are different for each chemical group (POWLES; YU, 2010). Thus, it is common for there to be a difference in grass control efficiency between the chemical groups. This also justifies the use of admixtures in resistance prevention and management. If a mutation occurs that involves the substitution of a specific amino acid for FOPs binding, resistance will not occur for DIMs, and vice versa, except for the positions 2078 and 2088 previously described. This pattern may explain sourgrass resistance only to FOP herbicides in Brazil, since these plants remain susceptible to DIMs (HEAP, 2019).

The association of 2,4-D to the graminicides clethodim and quizalofop, in general, resulted in antagonism, reducing the control of sourgrass in the present study. The reduction of efficiency occurred mainly for quizalofop, reaching $39 \%$ in the recommended dose at 28 DAT (Figure 4D). For the herbicide clethodim, this effect was approximately $8 \%$ (Figure 1D). Similar results were observed in works with different oat species, which verified that 2,4-D presented an antagonistic relation with FOPs herbicides (clodinafop-propargyl and diclofopmethyl (TODD; STOBBE, 1980; KAFIZ et al., 1989). Similarly, Trezzi et al. (2007) mentioned the occurrence of antagonism between quizalofop and 2,4-D in the control of ryegrass (Lolium multiflorum).

Several explanations are given in the literature for the occurrence of antagonism between 2,4-D and ACCase inhibitors in poaceae, mainly with FOPs, as found in the present study. The absorption of diclofop-methyl in Avena fatua was reduced when the herbicide was applied in a tankmix with 2,4-D (TODD; STOBBE, 1980). In addition, the authors found that when applied in a mixture, the translocation of the graminicide to roots and apices of the aerial parts was lower, resulting in membrane damage and occurrence of necrosis in the leaves that received the herbicide. The same results were observed in the present study (Figure 2), in which both clethodim and quizalofop, as well as the association of both, when applied together with 2,4$\mathrm{D}$, resulted in necrosis in the first days after application.

For the herbicide clethodim, at doses below that recommended, mixture with 2,4-D resulted in synergism and, with at last the recommended dose, 
the association resulted in antagonism (Figure 1). In general, poaceae weeds have a lot of wax in crystallized form, whereas in broadleaved weeds the wax is predominantly amorphous (WANG; LIU, 2007). The higher the amount of wax in crystallized form, the lower the contact angle, the retention of the spray solution and the diffusion of the herbicides through the waxy layer, hindering the capacity to absorb chemical compounds (HESS; FOY, 2000). Thus, it is possible that 2,4-D saturated the absorption capacity by the cuticle of the sourgrass plants, justifying the occurrence of antagonism only in doses above the recommended.

For the herbicide quizalofop, antagonism occurred in virtually all doses in the final control evaluations (Figures 4C and 4D). This can be explained by the metabolization of this graminicide, which produces compounds that are less toxic to plants. This phenomenon is common for FOPs herbicides, and it can be pointed as the cause of resistance in some weeds (YU; POWLES, 2014). The association of 2,4-D to the herbicide diclofopmethyl stimulated the defense of ryegrass (Lolium multiflorum) (HAN et al., 2013). When the auxinic herbicide was associated to diclofop-methyl, the ryegrass plants were tolerant even in the susceptible population. The authors attributed this response to increased expression of $P 450$ genes, which encode enzymes responsible for the degradation of various classes of herbicides.

When clethodim was associated with quizalofop, antagonism due to 2,4-D was observed only for some doses of the graminicide admixture that were below the one recommended, in the final control evaluations (Figures 6C and 6D). In the other doses, the antagonistic effect resulting from the addition of 2,4-D was non-existent. This fact can be explained by the use of only $50 \%$ of the dose of each herbicide. Since they have different physicochemical characteristics, the absorption and translocation vary between clethodim (log Kow: 1.6; pKa: 4.1) and quizalofop (log Kow: 4.66; pKa: 1.25) (SENSEMAN, 2007).

Another factor that may explain the occurrence of antagonism between ACCase inhibitors and 2,4-D is membrane polarity, as observed in experiments with oats (SHIMABUKURO; WALSH; WRIGHT, 1989). Auxins, such as 2,4-D, have several functions, among them maintaining the electrical potential of the membranes. In contrast, ACCase inhibitors, in addition to inhibiting lipid synthesis, act in opposite to auxins, altering the electrical gradient of the membranes. Thus, these herbicides act in an antagonistic way, which can explain, at least in part, the reduction of efficiency when the herbicides are applied in mixture (COBB; READE, 2010). Thus, the antagonism would be reciprocal, that is, the graminicide would also cause reduction of the activity of the broadleaf herbicide (SHIMABUKURO; WALSH; WRIGHT, 1989). As such, there is a need to assess if the graminicides used in the control of sourgrass also reduce the efficiency of 2,4-D in the control of broadleaf plants, such as horseweed.

Due to the occurrence of antagonism between the herbicides used in this work, two measures could be taken. The first would be increase the dose of graminicides when associated to 2,4-D to reach the same control obtained by the isolated application. However, the present study observed that increased doses of graminicides did not result in an increase in control when in association with 2,4-D. The other measure would be the sequential application of these herbicides, waiting for an interval that minimized the antagonistic effect. The second experiment showed that a period of nine and 12 days would be enough for the herbicides clethodim and quizalofop, respectively, so that the control of sourgrass would not be diminished (Figure 9). These results corroborate with those found for Avena fatua, in which a ten-day interval between the application of 2,4-D and diclofop-methyl was enough so that there was no reduction in the efficiency of the graminicide (KAFIZ et al., 1989).

\section{CONCLUSIONS}

The association of 2,4-D to the graminicides clethodim and quizalofop- $P$-tefuril results in antagonism in the control of sourgrass. The greatest antagonistic effect was observed for quizalofop- $P$ tefuril, with reduction of up to $39 \%$ in the control at the recommended dose. For clethodim, the addition of 2,4-D to the spray solution resulted in $8 \%$ of reduction of control. However, when clethodim and quizalofop- $P$-tefuril were applied in admixture, the addition of 2,4-D did not impair the control.

In order for antagonism not to occur, a minimum interval between the application of 2,4-D and the graminicides must be respected. For clethodim, nine days are necessary after the application of the auxinic herbicide for graminicide to be applied without compromising the control of sourgrass. For quizalofop- $P$-tefuril, this period is longer: 12 days. 
RESUMO: Os herbicidas inibidores da ACCase são amplamente utilizados no controle de poáceas, tal como o capim-amargoso. No entanto, esses herbicidas são seletivos para plantas eudicotiledôneas, o que demanda a utilização de herbicidas latifolicidas, tais como as auxinas sintéticas, em áreas que existam plantas daninhas de folhas largas e folhas estreitas. O objetivo deste trabalho foi avaliar o efeito da associação de inibidores da ACCase e 2,4-D sobre o controle de capim-amargoso. Foram realizados dois experimentos em casa de vegetação. No primeiro experimento foi avaliado o efeito da associação de 2,4-D aos graminicidas no controle de capim-amargoso, utilizando-se curvas de dose-resposta para os herbicidas clethodim, quizalofop- $P$ tefuril e clethodim + quizalofop- $P$-tefuril. No segundo experimento, em decorrência dos resultados do primeiro, foi avaliado o período necessário entre a aplicação de 2,4-D e os graminicidas para que não ocorra antagonismo em capim-amargoso. Os resultados demonstram que para o herbicida clethodim, na dose recomendada, a redução de controle foi de cerca de $8 \%$ quando o 2,4-D foi aplicado em associação. Já para o herbicida quizalofop- $P$-tefuril, esse efeito foi superior, causando redução de $39 \%$ no controle. Porém, a associação do 2,4-D à mistura de clethodim + quizalofop- $P$-tefuril não resultou em antagonismo. São necessários nove e 12 dias entre a aplicação de 2,4-D e os graminicidas clethodim e quizalofop- $P$-tefuril, respectivamente, para que não ocorra antagonismo.

PALAVRAS-CHAVE: Mistura de tanque de herbicidas. Antagonismo. Clethodim. Quizalofop- $P$ tefuril. Digitaria insularis.

\section{REFERENCES}

BARROSO, A. L. L.; DAN, H. A.; PROCÓPIO, S. O.; TOLEDO, R. E. B.; SANDANIEL, C. R.; BRAZ, G. B. P.; CRUVINEL, K. L. Efficacy of ACCase-inhibiting herbicides in controlling grass weeds in soybean crops. Planta Daninha, Viçosa, v. 28, n. 1, p. 149-157, 2010. https://doi.org/10.1590/S0100-83582010000100018

BARROSO, A. A. M.; ALBRECHT, A. J. P.; REIS, F. C.; FILHO, R. V. Accase and glyphosate diferent formulations herbicides association interactions on sourgrass control. Planta Daninha, Viçosa, v. 32, n. 3, p. 619-627, 2014. https://doi.org/10.1590/S0100-83582014000300018

BURKE, I. C.; THOMAS, W. E.; BURTON, J. D.; SPEARS, J. F.; WILCUT, J. W. A Seedling assay to screen aryloxyphenoxypropionic acid and cyclohexanedione resistance in johnsongrass (Sorghum halepense). Weed Technology, Champaign, v. 20, n. 4, p. 950-955, 2006. https://doi.org/10.1614/WT-05-160.1

CARVALHO, L. B.; CRUZ-HIPOLITO, H.; GONZÁLEZ-TORRALVA, F.; ALVES, P. L. C. A.; CHRISTOFFOLETI, P. J.; DE PRADO, R. Detection of sourgrass (Digitaria insularis) byotipes resistant to glyphosate in Brazil. Weed Science, Champaign, v. 59, n., p. 171-176, 2011. https://doi.org/10.1614/WS-D-1000113.1

COBB, A. H.; READE, J. P. H. Herbicides and Plant Physiology. 2 ed. Newport: Wiley-Blackwell, 2010. 296 p. https://doi.org/10.1002/9781444327793

HAN, H.; YU, Q.; CAWTHRAY, G. R.; POWLES, S. B. Enhanced herbicide metabolism induced by 2,4-D in herbicide susceptible Lolium rigidum provides protection against diclofop-methyl. Pest Management Science, London, v. 69, n. 9, p. 996-1000, 2013. https://doi.org/10.1002/ps.3552

HEAP, I. The International Survey of Herbicide Resistant Weeds. Online. Internet, April 4, 2019. Avaiable: $<$ http://www.weedscience.org $>$.

HESS, F. D.; FOY C. L. Interaction of surfactants with plant cuticles. Weed Technology, Champaign, v. 14, n. 4, p. 807-813, 2000. https://doi.org/10.1614/0890-037X(2000)014[0807:IOSWPC]2.0.CO;2

KAFIZ, B.; CAUSSANEL, J. P.; SCALLA, R.; GAILLARDON, P. Interaction between diclofop-methyl and 2,4-D in wild oat (Avena fatua L.) and cultivated oat (Avena sativa L.), and fate of diclofop-methyl in cultivated oat. Weed Research, Oxford, v. 29, n. 4, p. 299-305, 1989. https://doi.org/10.1111/j.13653180.1989.tb00915.x 
LAMEGO, F. P.; VIDAL, R. A. Resistance to glyphosate in Conyza bonariensis and Conyza canadensis biotypes in Rio Grande do Sul, Brazil. Planta Daninha, Viçosa, v. 26, n. 2, p. 467-471, 2008. https://doi.org/10.1590/S0100-83582008000200024

LAZAROTO, C. A.; FLECK, N. G.; VIDAL, R. A. Biology and ecophysiology of hairy fleabane (Conyza bonariensis) and horseweed (Conyza canadensis). Ciência Rural, Santa Maria, v. 38, n. 3, p. 852-860, 2008. https://doi.org/10.1590/S0103-84782008000300045

LIU, W.; HARRISON, D. D.; CHALUPSKA, D.; GORNICKI, P.; O’DONNELL, C. C.; ADKINS, S. W.; HASELKORN, R.; WILIAMS, R. R. Single-site mutations in the carboxyltransferase domain of plastid acetylCoA carboxylase confer resistance to grass-specific herbicides. Proceedings of the National Academy of Sciences, Washington, v. 104, n. 9, p. 3627-3632, 2007. https://doi.org/10.1073/pnas.0611572104

LÓPEZ-OVEJERO R. F.; TAKANO, H. K.; NICOLAI, M.; FERREIRA, A.; MELO, M. S. C.; CAVENAGHI, A. L.; CHRISTOFFOLETI, P. J.; OLIVEIRA, R. S. Frequency and dispersal of glyphosate-resistan sourgrass (Digitaria insularis) populations across brasilian agricultural production áreas. Weed Science, Champaign, v. 65, n. 2, p. 285-296, 2017. https://doi.org/10.1017/wsc.2016.31

NALEWAJA, J. D.; MATYSIAK, R.; SZELEZNIAK, E. F. Sethoxydim response to spray chemical properties and environment. Weed Technology, Champaign, v. 8, n. 3, p. 591-597, 1994.

https://doi.org/10.1017/S0890037X00039749

POWLES, S.; YU, Q. Evolution in action: plants resistant to herbicides. Annual Review of Plant Biology, Palo Alto, v. 61, n. 1, p. 317-347, 2010. https://doi.org/10.1146/annurev-arplant-042809-112119

RENDINA, A. R.; CRAIG-KENNARD, A. C.; BEAUDOIN, J. D.; BREEN, M. K. Inhibition of acetylcoenzyme A carboxylase by two classes of grass-selective herbicides. Journal of Agriculture and Food Chemistry, Easton, v. 38, n. 5, p. 1282-1287, 1990. https://doi.org/10.1021/jf00095a029

SENSEMAN, S. A. Herbicide handbook. 9. ed. Lawrence: Weed Science Society of America, 2007. 458 p.

SHIMABUKURO, R. H.; WALSH, W. C.; WRIGHT, J. P. Effect of diclofop-methyl and 2,4-D on transmembrane proton gradient: a mechanism for their antagonistic interaction. Physiologia Plantarum, Copenhagen, v. 77, n. 1, p. 107-114, 1989. https://doi.org/10.1111/j.1399-3054.1989.tb05985.x

TODD, B. G.; STOBBE, E. H. The basis of the antagonism effect of the 2,4-D on diclofop-methyl toxicity to wild oat (Avena fatua). Weed Science, Champaign, v. 28, n. 4, p. 371-377, 1980.

https://doi.org/10.1017/S0043174500055508

TREZZI, M. M.; MATTEI, D.; VIDAL, R. A.; KRUSE, N. D.; GUSTMAN, M. S.; VIOLA, R.; MACHADO, A.; SILVA, H. L. Antagonismo das associações de clodinafoppropargyl com metsulfuron methyl e 2,4-D no controle de azevém (Lolium multiflorum). Planta Daninha, Viçosa, v. 25, n. 4, p. 839-847, 2007. https://doi.org/10.1590/S0100-83582007000400021

VARGAS, L.; BIANCHI, M. A.; RIZZARDI, M. A.; AGOSTINETTO, D.; DAL MAGRO, T. Conyza bonariensis biotypes resistant to the glyphosate in southern Brazil. Planta Daninha, Viçosa, v. 25, n. 3, p. 573578, 2007. https://doi.org/10.1590/S0100-83582007000300017

WANG, C. J.; LIU, Z. Q. Foliar uptake of pesticides - Present status and future challenge. Pesticide Biochemistry and Physiology, San Diego, v. 87, n. 1, p. 1-8, 2007.

https://doi.org/10.1016/j.pestbp.2006.04.004

YU, Q.; POWLES, S. B. Metabolism-based herbicide resistance and cross-resistance in crop weeds: a threat to herbicide sustainability and global crop production. Plant Physiology, Minneapolis, v. 66, n. 3, p. 1106-1118, 2014. https://doi.org/10.1104/pp.114.242750 